\title{
Fat content in Black Sea sprat as an indicator of fish food supply and ecosystem condition
}

\author{
Georgiy E. Shulman ${ }^{1, *}$, Victor N. Nikolsky ${ }^{1}$, Tatyana V. Yuneva ${ }^{1}$, Galina S. Minyuk ${ }^{1}$, \\ Vladimir Ya. Shchepkin ${ }^{1}$, Alla M. Shchepkina ${ }^{1}$, Elena V. Ivleva ${ }^{1}$, Oleg A. Yunev ${ }^{1}$, \\ Ivan S. Dobrovolov ${ }^{2}$, Ferit Bingel ${ }^{3}$, Ahmet E. Kideys ${ }^{3}$ \\ ${ }^{1}$ Institute of Biology of the Southern Seas, National Academy of Sciences of Ukraine, Nakhimov Av. 2, \\ Sevastopol 99011, Crimea, Ukraine \\ ${ }^{2}$ Institute of Fishery Resources, Primorsky Bulv. 4, Varna 9000, Bulgaria \\ ${ }^{3}$ Middle East Technical University, Institute of Marine Sciences, PO Box 28, 33731 Erdemli, Mersin, Turkey
}

\begin{abstract}
Fat content (as \% of total body wet wt) of the sprat Sprattus sprattus phalericus in the Black Sea was determined annually during the peak feeding period (i.e. summer) between 1960 and 2001. Interannual variations of this characteristic were quite high (from 8.0 to $16.0 \%$ ). Sprat fat content can be used as an indicator of food supply (or recent feeding history). In the Black Sea, different periods could be distinguished with respect to food supply of this species: Period I (1960 to 1964) with stable sprat fat content values of 11.2 to $13.7 \%$; Period II (1965 to 1972) with decreased values of 8.5 to $10.3 \%$; Period III (1974 to 1982) with higher values of 11.4 to $15.7 \%$; Period IV (1983 to 1990) when there were the highest interannual fluctuations and a decrease to 9.9 to $10.7 \%$; Period V (1991 to 1997) again with high fat content values of 12.2 to $14.7 \%$; Period VI (1998 to 2001) with stabilized fat content values of 12.0 to $12.3 \%$. These periods are closely related to the general situation in the Black Sea ecosystem caused by climatic changes, increased trophic competition, eutrophication and pollution. Relationships between interannual fluctuations in sprat fat content, on the one hand, and sprat biomass and phytoplankton concentration, on the other, are revealed. The features of the interannual dynamics of the Black Sea sprat fat content are similar to those (biomass and catches) of small pelagic fishes in the Mediterranean and in some other parts of the World Ocean.
\end{abstract}

KEY WORDS: Sprat - Sprattus sprattus phalericus - Black Sea - Fat content - Food supply · Interannual periods $\cdot$ Stock biomass $\cdot$ Phytoplankton $\cdot$ Mesozooplankton

\section{INTRODUCTION}

The condition of marine fish stocks is usually characterized using data on abundance, biomass, catches, length-weight composition, sex ratio, distribution etc. (Ivanov \& Beverton 1985, Caddy \& Griffiths 1990, Laevestu 1993, Caddy \& Oliver 1994, Prodanov et al. 1997, Chashchin 1998, Sinovcic 2000, Daskalov 2002). However, it is surprising that no reference is made to the food supply (or provision), despite the fact that food is one of the major factors connecting organisms with their environment.
Food supply of organisms or populations $\left(F_{\mathrm{s}}\right)$ could be described as the ratio between food consumed $\left(F_{\mathrm{c}}\right)$ and required $\left(F_{\mathrm{r}}\right)$ :

$$
F_{\mathrm{s}}=F_{\mathrm{c}} / F_{\mathrm{r}}
$$

The direct determination of these characteristics in field conditions is very difficult. The indirect determination of organism and population food supply is also confronted with serious problems since food supply is dependent on many factors including some that cannot be defined: 


$$
F_{\mathrm{s}}=f\left(A_{\mathrm{b}}, A_{\mathrm{ba}}, A_{\mathrm{c} 1}, \ldots, A_{\mathrm{cn},} T, L, \ldots, X_{1}, \ldots, X_{\mathrm{n}}\right)
$$

where $A_{\mathrm{b}}$ is the biomass of fodder organisms, $A_{\mathrm{ba}}$ is their availability, $A_{\mathrm{c} 1}, \ldots, A_{\mathrm{c} n}$ is the biomass of consumers of own species as well as competitors of other species, $T$ is temperature, $L$ is illumination (which is especially important for aquatic organisms), and $X_{1}, \ldots$, $X_{n}$ are undefined factors.

Nevertheless, there is a rather effective way of estimating food supply, which is the determination of one of the end products of the feeding process which reflects nutritional condition, such as weight increment $(\Delta W)$ and accumulation of energy reserves $(\Delta E)$. In the case of marine fish species, fat reserves can be examined:

$$
\Delta W, \Delta E=f\left(F_{\mathrm{s}}\right)
$$

Determining the weight increment in field conditions is also not an easy task; however, estimating fat content is an easy and useful method for evaluating the condition of fish. This process of energy accumulation begins every year almost from 'zero' following the spawning period and reaches a peak at the end of the intense feeding period. The content of reserve lipids at the time of feeding completion is, therefore, an integral indicator of conditions under which fish stocks or populations were fed (that is to say 'the food supply'):

$$
F A T=\int_{t_{1}}^{t_{2}} f\left(F_{\mathrm{s}}\right) \mathrm{d} t
$$

Determination of fat content is widely used for evaluating fish condition (see reviews: Shulman 1960, Lovern 1964, Love 1970, 1980, Ackman 1980, Shatunovsky 1980, Kreps 1981, Sidorov 1983, Minyuk et al. 1997). Unfortunately, however, most of these investigations did not look at the problem from a food supply point of view. Among the very few papers that have been published on the characterization of the feeding history of fish are those in which the food supply of larvae of Atlantic sardine Sardina pilchardus (Fraser et al. 1988) and Californian anchovy Engraulis mordax (Hakanson 1989a,b) was estimated using lipid parameters.

Assessments of the food supply of several marine fish populations by determination of accumulated fat stores (fat content) have been carried out by some authors since the 1960s (Shulman 1963, 1974, Shulman \& Love 1999). These investigations were devoted to Azov and Black Sea subspecies of European anchovy Engraulis encrasicolus maeoticus and E. e. ponticus (Shulman \& Dobrovolov 1979) and Black Sea sprat Sprattus sprattus phalericus (Shulman et al. 1994, Minyuk et al. 1997). Sprat and anchovy are the 2 main small pelagic fish species of the Black Sea and have significant effects on the ecosystem. Sprat is a cold-tolerant, planktivorous fish, spawning in winter and forming local populations. It feeds intensively in spring and at the start of summer (Svetovidov 1964), with considerable fat stores (about 10 to $15 \%$ of body mass; Shulman 1966) accumulating in June to August. We can characterize 'the degree of well-being' of sprat condition by estimating its fat content at the end of the intensive feeding period. Moreover, sprat condition in this period could be an indicator of the whole of the Black Sea's pelagic ecosystem.

The aim of our investigation was to trace the longterm changes in food supply of the Black Sea sprat stocks based on determination of their fat content dynamics. To this end, the objectives of investigation were to review how the characteristic studied was connected with (1) dynamics of sprat stock biomass, (2) dynamics of biomass of the lower trophic levels (i.e. zoo- and phytoplankton), and (3) stock condition of anchovy (the other mass pelagic fish in the Black Sea) as well as pelagic fishes of the Mediterranean and other basins of the World Ocean.

\section{MATERIALS AND METHODS}

The data on the Black Sea sprat fat content in this paper are based on samples obtained from the regions of main concentration of this species: the western coasts of Crimea (Region 1), the shelf zone of Romania and Bulgaria (Region 2), and the Caucasus coasts (Region 3) (Fig. 1). Fish were caught with trawling either by research or commercial vessels in summer (June to August) every year from 1960 until 2001 (excluding 1966, 1973, 1975 and 1993). Information about the samples obtained is presented in Table 1. A mean randomized sample of fish (about 100 ind.) was selected from every catch, which usually contained specimens of 60 to $90 \mathrm{~mm}$ in length. Fish were sorted at $5 \mathrm{~mm}$ size intervals, and then a minimum of 10 ind. from each size group were included in analyses. Hence, 4 to 5 dominant size groups were taken from every catch. Every group was separately homogenized. About 10 to $15 \mathrm{~g}$ of homogenate was dried in an oven at $100^{\circ} \mathrm{C}$ to a constant weight.

Fat content in dry matter was determined by the weight method with diethyl ether extraction in a Soxhlet apparatus (Ackman 1980) between 1960 and 1984. This method of extraction was adequate to investigate triacylglycerol levels, the main energy reserves in the fish of the family Clupeidae (Hardy \& Mackie 1969, Ackman 1980, Minyuk et al. 1997), and a very appreciable component of the extracted lipids. A comparison of the results obtained by ether and chloroformmethanol (2:1) extractions was carried out (Minyuk et 


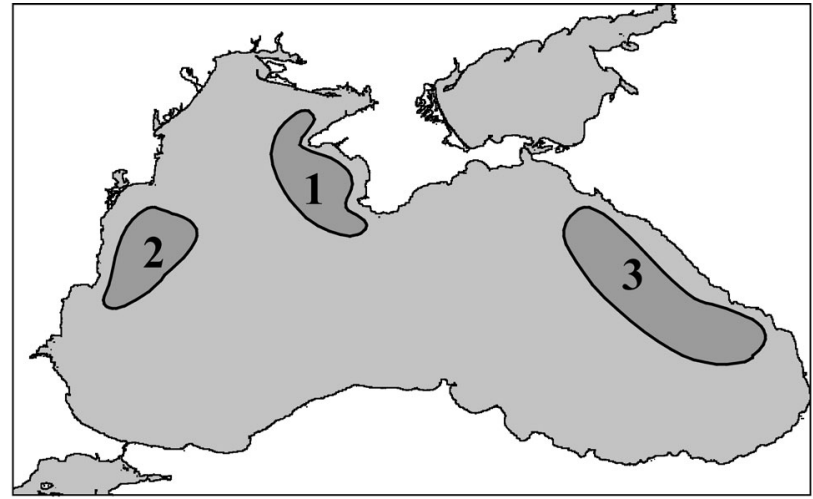

Fig. 1. Sprat sampling locations in the Black Sea. 1: northwestern part of the sea (off the eastern Crimea); 2: western part of the sea (off Romania and Bulgaria); 3: eastern part of the sea (off Caucasus)

Table 1. Number of analyzed samples

\begin{tabular}{|c|c|c|c|}
\hline Year & $\begin{array}{c}\text { Region } \\
\text { (sampling locations) }\end{array}$ & $\begin{array}{l}\text { No. of } \\
\text { trawls }\end{array}$ & $\begin{array}{c}\text { No. of } \\
\text { samples }\end{array}$ \\
\hline 1960 & $1,2,3$ & 12 & 34 \\
\hline 1961 & $1,2,3$ & 11 & 24 \\
\hline 1962 & $1,2,3$ & 11 & 34 \\
\hline 1963 & 3 & 3 & 7 \\
\hline 1964 & 3 & 1 & 2 \\
\hline 1965 & 3 & 1 & 3 \\
\hline 1967 & 1,3 & 2 & 10 \\
\hline 1968 & 1,3 & 2 & 10 \\
\hline 1969 & 1,3 & 2 & 10 \\
\hline 1970 & 1,3 & 2 & 10 \\
\hline 1971 & 1,3 & 2 & 10 \\
\hline 1972 & 1,3 & 2 & 10 \\
\hline 1974 & 2 & 1 & 5 \\
\hline 1976 & 2 & 1 & 3 \\
\hline 1977 & 1,2 & 8 & 29 \\
\hline 1978 & 2 & 1 & 7 \\
\hline 1979 & 2 & 2 & 7 \\
\hline 1980 & 2 & 2 & 4 \\
\hline 1981 & 1,2 & 10 & 44 \\
\hline 1982 & 1,2 & 6 & 27 \\
\hline 1983 & $1,2,3$ & 5 & 18 \\
\hline 1984 & 1,2 & 6 & 22 \\
\hline 1985 & 1,2 & 14 & 53 \\
\hline 1986 & 2,3 & 12 & 54 \\
\hline 1987 & $1,2,3$ & 15 & 57 \\
\hline 1988 & 1,2 & 3 & 15 \\
\hline 1989 & 1,2 & 4 & 22 \\
\hline 1990 & 1,3 & 5 & 28 \\
\hline 1991 & 1,3 & 3 & 13 \\
\hline 1992 & 1,3 & 4 & 14 \\
\hline 1994 & 1 & 3 & 10 \\
\hline 1995 & 1 & 3 & 13 \\
\hline 1996 & 1 & 4 & 8 \\
\hline 1997 & 1 & 5 & 15 \\
\hline 1998 & 1 & 5 & 20 \\
\hline 1999 & 1 & 5 & 15 \\
\hline 2000 & 1 & 5 & 15 \\
\hline 2001 & 1 & 5 & 20 \\
\hline Total & & 188 & 702 \\
\hline
\end{tabular}

al. 1997). It was shown that the recovery ratio for sprat is $0.83: 1$. On the basis of the results obtained by ether extraction, the linear regression between fat $(Y)$ and dry matter $(X)$ content in sprat body was calculated ( $\mathrm{n}=300 ; \mathrm{r}=0.9$ ) (Minyuk et al. 1997):

$$
Y=-13.28+0.84 X
$$

were $Y$ and $X$ are expressed in \% of wet wt. Since 1985, fat content was determined by a calculation method based on the data for dry matter content. This calculation method has allowed us to simplify the procedure applied, to make it easily available, rapid, and to apply it over a large collection of representative data. This made it possible to complete all analyses not only in a stationary laboratory but also on board the vessel. Later, the methods used will allow us to compare our results with a considerable massive data base on fat content of large number of fish species obtained from the beginning of the past century until the 1960s, when only the diethyl ether extraction method was widely used.

All 702 sprat samples were analyzed (about 19000 fish) from 188 different catches $(90,56$ and 42 catches from Regions 1, 2 and 3, respectively). Statistical analyses of the data obtained followed. Mean values of sprat fat content for every catch were calculated. Average fish fat content for every region was calculated on the basis of these mean values. Spatial variability of sprat fat content was estimated for those years for which there were samples from compared regions. As is pointed out in Table 1, simultaneous determination in all 3 regions was carried out for 5 years (1960 to 1962, 1983 and 1987); there are data for some other years (1967 to $1972,1977,1981,1982,1984$ to 1986,1988 to 1992) that are simultaneous for 2 regions. For each case, a null-hypothesis was put forward to check the absence of differences in sprat fat content from different regions by using single factor analysis of variance (ANOVA) and a 2-sample hypothesis testing for difference between 2 means (Zar 1984). For analysing the temporal (interannual) variability of data, factorial ANOVA was also used.

\section{RESULTS}

Average values and their standard errors of Black Sea sprat fat content during the intense feeding period (summer months) in 1960 to 2001 are represented in Table 2 for every region. Statistical analysis did not show significant spatial variations in fish fat content from different regions (excluding a single case in 1990) compared to interannual differences. The data for 3 regions were, therefore, pooled and further analyzed as a common temporal data set. 
Results of ANOVA on temporal variability showed that interannual variation was higher than spatial variation, being equal to $465 / 713=0.652$, i.e. about $65 \%$ of total dispersion (Table 3 ). The mean value of error for a single observation can be obtained as the square root of dispersion MS (within groups):

$$
s d=\sqrt{1.653} \approx 1.29
$$

An error for the mean value from several observations was then calculated with the formula:

$$
m=\frac{s d}{\sqrt{n}} \approx \frac{1.29}{\sqrt{n}}
$$

where $n$ is the number of observations (catches) during the year. The values of standard errors calculated by this method are represented in the last column of Table 2 .

The average long-term fat content of sprat was $11.74 \pm 0.28 \%$ but fluctuated considerably from year to year (interannual coefficient of variation $\mathrm{CV}=$ $14.6 \%$ ). The analysis of the curve obtained allowed us to tentatively select several periods in interannual fat content dynamics of sprat (Fig. 2). Period I (1960 to 1964) was the 'start' of our examination when fat content values (range 11.2 to $13.7 \%$ ) were generally higher than the interannual mean. Period II (1965 to 1972) was characterized by decreases in fat content to 8.5 to $10.3 \%$. Period III (1974 to 1982) displayed increased fat content values from 11.4 to $15.7 \%$ (excluding 1979). In Period IV (1983 to 1990), fat content values again decreased and large interannual fluctuations occurred (range 9.9 to $12.8 \%$ ). In Period V (1991 to 1997), fat content recovered with high values of 12.2 to $14.7 \%$, and in Period VI (1998 to 2001), excluding 1999, fat content values (range 12.0 to $12.3 \%$ ) were close to the average magnitude for the entire long-term period.

Table 3. Results of ANOVA for interannual variability of sprat fat content

\begin{tabular}{|lcccccc|}
\hline $\begin{array}{l}\text { Source of } \\
\text { variation }\end{array}$ & SS & df & MS & $F$ & p & $\begin{array}{c}F \\
\text { critical }\end{array}$ \\
\hline $\begin{array}{l}\text { Between groups } \\
\text { (years) }\end{array}$ & 464.97 & 37 & 12.567 & 7.604 & 0.000 & 1.490 \\
$\begin{array}{l}\text { Within groups } \\
\text { (years) }\end{array}$ & 247.90 & 150 & 1.653 & & & \\
Total & 712.87 & 187 & & & & \\
\hline
\end{tabular}

\begin{tabular}{|c|c|c|c|c|c|c|}
\hline \multirow[t]{2}{*}{ Year } & \multicolumn{5}{|c|}{ Region } & \multirow{2}{*}{ Average } \\
\hline & \multicolumn{2}{|c|}{1} & 2 & \multicolumn{2}{|c|}{3} & \\
\hline 1960 & \multicolumn{2}{|c|}{$12.32 \pm 0.35$} & $11.50 \pm 0.64$ & \multicolumn{2}{|c|}{$12.53 \pm 0.44$} & $12.31 \pm 0.37$ \\
\hline 1961 & \multicolumn{2}{|c|}{$10.77 \pm 1.31$} & $11.81 \pm 0.71$ & \multicolumn{2}{|c|}{$11.97 \pm 1.16$} & $11.47 \pm 0.39$ \\
\hline 1962 & \multirow{4}{*}{\multicolumn{2}{|c|}{$12.97 \pm 0.95$}} & $12.74 \pm 1.16$ & \multicolumn{2}{|c|}{$12.17 \pm 0.77$} & $12.71 \pm 0.39$ \\
\hline 1963 & & & & \multicolumn{2}{|c|}{$13.68 \pm 1.19$} & $13.68 \pm 0.74$ \\
\hline 1964 & & & & 11.25 & - & $11.25 \pm 1.29$ \\
\hline 1965 & & & & 8.97 & - & $8.97 \pm 1.29$ \\
\hline 1967 & \multicolumn{3}{|c|}{$10.38-$} & 10.20 & - & $10.29 \pm 0.91$ \\
\hline 1968 & \multicolumn{3}{|c|}{$8.36-$} & 8.72 & - & $8.54 \pm 0.91$ \\
\hline 1969 & \multicolumn{3}{|c|}{$10.00-$} & 9.62 & - & $9.81 \pm 0.91$ \\
\hline 1970 & \multicolumn{3}{|c|}{$9.40-$} & 9.34 & - & $9.37 \pm 0.91$ \\
\hline 1971 & \multicolumn{3}{|c|}{$8.52-$} & 9.00 & - & $8.76 \pm 0.91$ \\
\hline 1972 & \multirow{3}{*}{\multicolumn{2}{|c|}{$9.24-$}} & & 8.84 & - & $9.04 \pm 0.91$ \\
\hline 1974 & & & $11.40-$ & & & $11.40 \pm 1.29$ \\
\hline 1976 & & & $11.95-$ & & & $11.95 \pm 1.29$ \\
\hline 1977 & \multicolumn{2}{|c|}{$12.31 \pm 0.70$} & $14.57 \pm 0.39$ & & & $13.16 \pm 0.45$ \\
\hline 1978 & & $11.89 \pm-$ & & & $11.89 \pm 1.29$ \\
\hline 1979 & & & $10.58 \pm 0.02$ & & & $10.58 \pm 0.91$ \\
\hline 1980 & & $14.12 \pm 0.27$ & & & $14.12 \pm 0.91$ \\
\hline 1981 & \multicolumn{2}{|c|}{$15.67 \pm 0.25$} & $15.71 \pm 0.36$ & & & $15.69 \pm 0.41$ \\
\hline 1982 & \multicolumn{2}{|c|}{$13.22 \pm 0.49$} & $12.56 \pm 0.32$ & & & $13.00 \pm 0.52$ \\
\hline 1983 & \multicolumn{2}{|c|}{$9.11 \pm 0.31$} & $11.85 \pm 0.37$ & 10.37 & - & $10.46 \pm 0.57$ \\
\hline 1984 & \multirow{2}{*}{\multicolumn{2}{|c|}{$\begin{array}{l}12.26 \pm 0.34 \\
11.96 \pm 0.14\end{array}$}} & $10.77 \pm 0.19$ & & & $11.76 \pm 0.52$ \\
\hline 1985 & & & $12.84 \pm 0.28$ & & & $12.72 \pm 0.34$ \\
\hline 1986 & & $10.77 \pm 0.56$ & 11.69 & 0.24 & $11.54 \pm 0.37$ \\
\hline 1987 & $9.91=$ & 0.21 & $9.85 \pm 0.26$ & 9.92 & 0.85 & $9.88 \pm 0.33$ \\
\hline 1988 & 13.75 & - & $12.28 \pm 0.84$ & & & $12.77 \pm 0.74$ \\
\hline 1989 & 10.24 & - & $12.84 \pm 0.76$ & & & $12.19 \pm 0.64$ \\
\hline 1990 & $9.88=$ & 0.30 & & 13.62 & - & $10.63 \pm 0.57$ \\
\hline 1991 & $13.39=$ & & & 12.10 & 0.58 & $12.53 \pm 0.74$ \\
\hline 1992 & $14.57=$ & 0.62 & & 15.13 & - & $14.71 \pm 0.64$ \\
\hline 1994 & 12.16 & 0.57 & & & & $12.16 \pm 0.74$ \\
\hline 1995 & $13.34=$ & 0.11 & & & & $13.34 \pm 0.74$ \\
\hline 1996 & $13.34=$ & 0.22 & & & & $13.34 \pm 0.64$ \\
\hline 1997 & $13.73=$ & 0.17 & & & & $13.73 \pm 0.57$ \\
\hline 1998 & $12.31=$ & 0.21 & & & & $12.31 \pm 0.57$ \\
\hline 1999 & $9.97=$ & 0.10 & & & & $9.97 \pm 0.57$ \\
\hline 2000 & 12.14 & 0.11 & & & & $12.14 \pm 0.57$ \\
\hline 2001 & $11.98=$ & 0.50 & & & & $11.98 \pm 0.57$ \\
\hline Over & average & $\pm \mathrm{SE}$ & & 11.74 & 0.28 & \\
\hline
\end{tabular}

Table 2. Sprat fat content, $\%$ of wet wt (mean \pm SE) from different regions

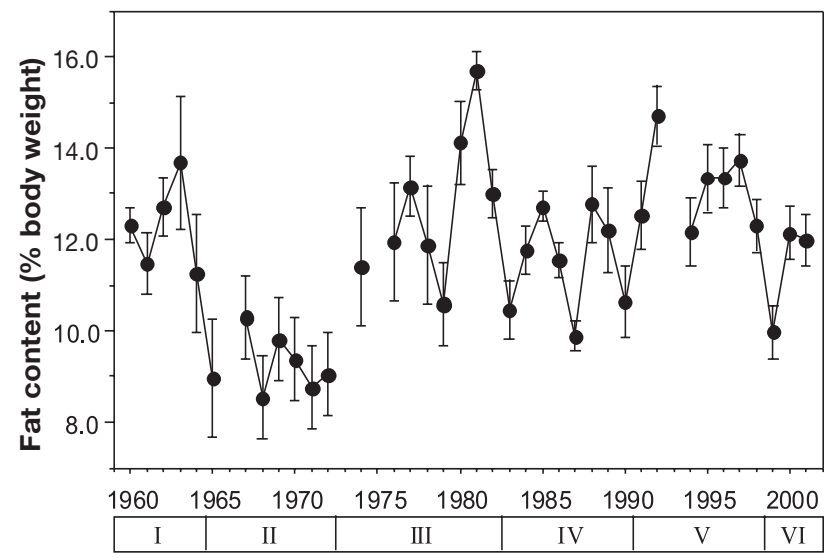

Fig. 2. Sprattus sprattus phalericus. Long-term variability of fat content of the Black Sea sprat and main periods (bottom of figure) in its dynamics. Values are mean $\pm \mathrm{SE}$ 

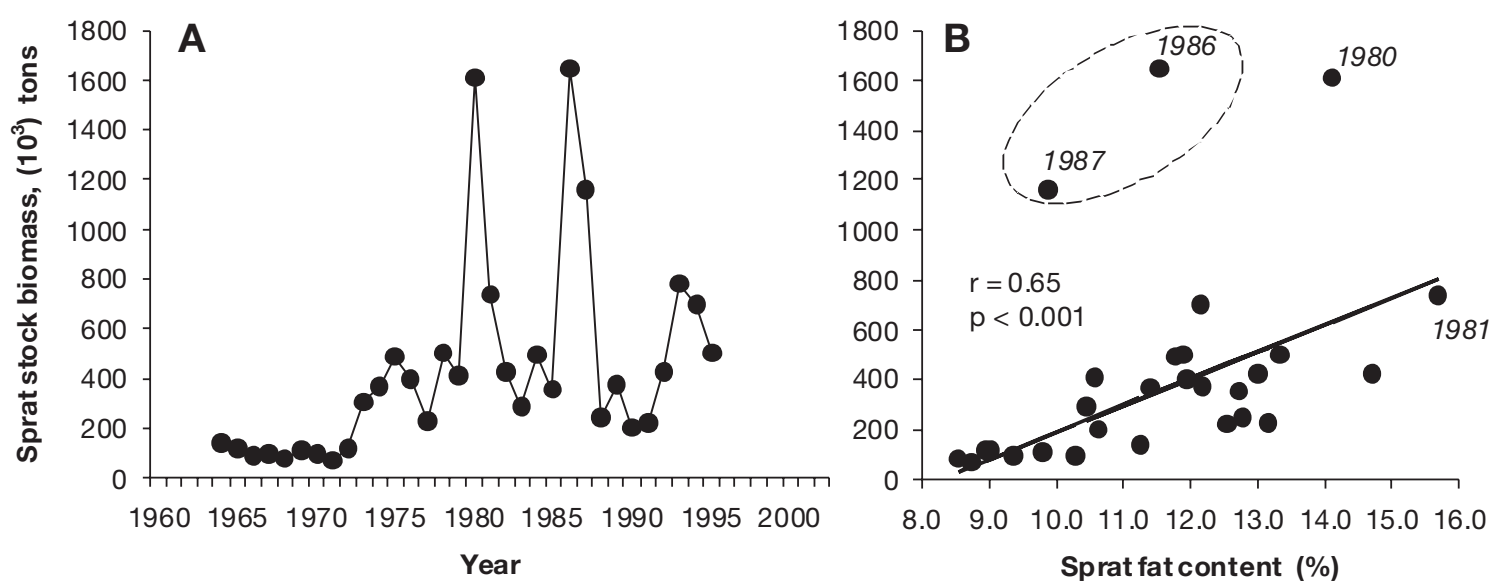

Fig. 3. Sprattus sprattus phalericus. (A) Long-term variability of sprat stock biomass in the Black Sea (after Domashenko et al. 1985, Chashchin 1998); (B) relationship between sprat fat content and stock biomass. The correlation coefficient was estimated without including the data corresponding to 1986 and 1987

\section{DISCUSSION}

\section{Relationship between sprat fat content and some other parameters of the Black Sea ecosystem}

The dynamics of the Black Sea sprat fat content are, to a large degree, similar to the long-term changes of stock value (biomass) of this fish, as determined from acoustical surveys and catches undertaken by the Kerch Institute of Marine Fishery and Oceanography, YugNIRO (Domashenko et al. 1985, Chashchin 1998) (Fig. 3A). Both fat content and stock biomass were at low levels in the second half of the 1960s and the beginning of the $1970 \mathrm{~s}$. The values of both parameters increased during most of the 1970s, the highest levels being reached at the beginning of the 1980s. Strong fluctuations in fat content and stock biomass were observed during the 1980s, followed by a decrease to low levels in 1990, and an increase in the following years. Two years (1986 and 1987) do not correspond to the general trend; high sprat biomass but low fat content values were obtained, the reasons for which are discussed in the next section. Overall, a positive relationship was revealed between fat content and sprat biomass (Fig. 3B). If the 2 years noted above are excluded from the analysis, the correlation between these parameters is rather high $(\mathrm{r}=0.65 ; \mathrm{p}<0.001)$.

In the Black Sea, sprat feed on mesozooplankton. The data on long-term variability of fodder (i.e. edible, excluding mass occurring gelatinous dinoflagellate Noctiluca scintillans) mesozooplankton biomass since 1960 until 1988 in the north-western part of the Black Sea (one of the feeding regions for planktivorous fishes) are represented in Fig. 4 (Kovalev et al. 1998). For most of the investigation period, a resemblance between data on mesozooplankton density and on fat content or sprat stock biomass was not observed. However, a positive trend between the dynamics of sprat fat content and phytoplankton biomass (Mikaelyan 1997) in the Black Sea was revealed (Fig. 5).

\section{Sprat fat content as an indicator of stock condition}

The data on the long-term dynamics of fat content in sprat stock show that its food supply in the Black Sea fluctuates considerably. A decrease in sprat fat content and consequently in food supply is observed between the first half of the 1960s and the early 1970s. During this period, concentrations of phytoplankton were stable and low (Mikaelyan 1997), or even decreased (Bryantseva et al. 1996). Primary production was also reported to be low during this period (Vedernikov \& Demidov 1993). Sprat stock biomass (according to surveys in May) were low (Domashenko et al. 1985,

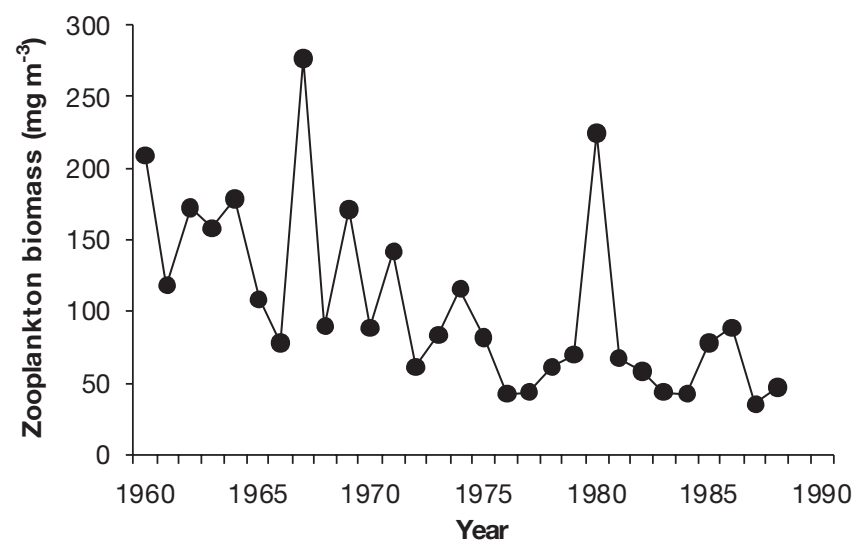

Fig. 4. Long-term variability of food mesozooplankton biomass (without Noctiluca) in the north-western part of the Black Sea (after Kovalev et al. 1998) 

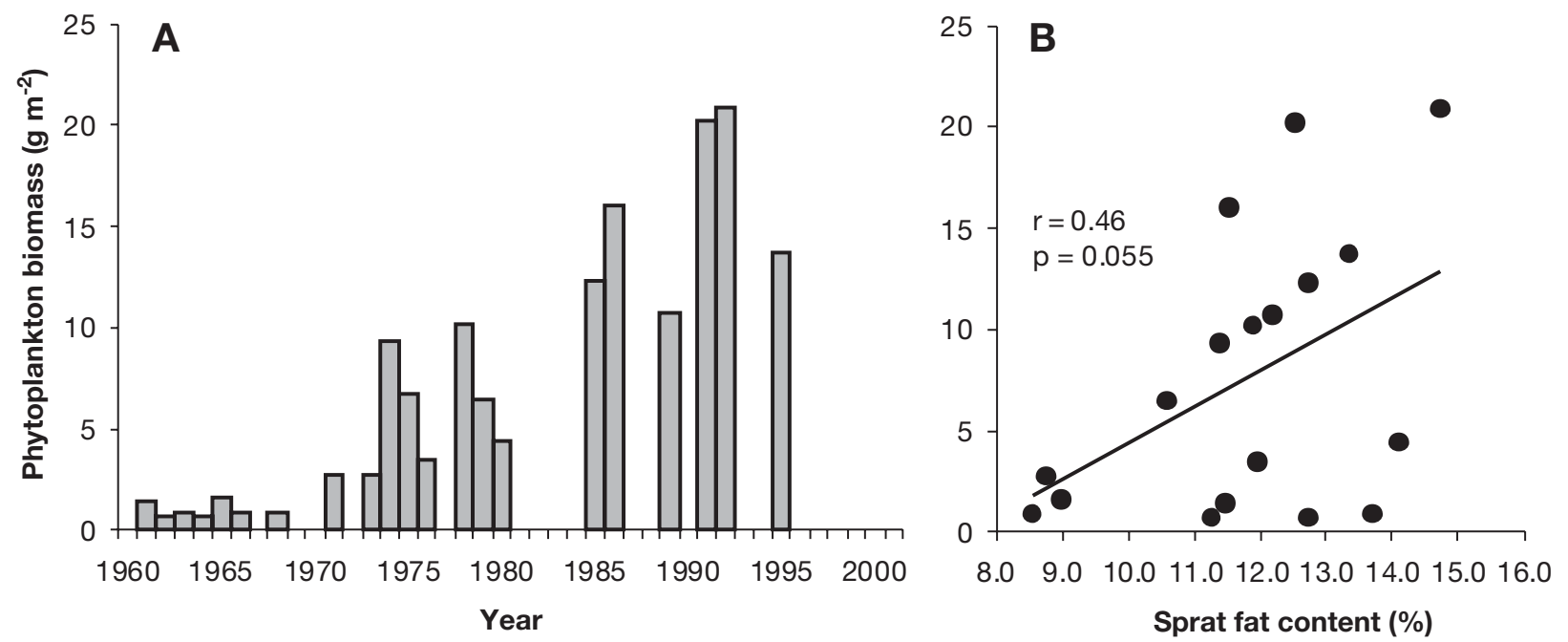

Fig. 5. (A) Long-term variability of total phytoplankton biomass in the Black Sea (after Mikaelyan 1997); (B) relationship between sprat fat content and phytoplankton biomass in the Black Sea

Chashchin 1998). In the Black Sea, the second half of the 1970 s and the entire 1980s were characterized by an increase in eutrophication (Vinogradov et al. 1992, Zaitsev 1993, Sorokin 2002). In the beginning, the eutrophication was accompanied by an increase in sprat fat content and stock biomass (Period III, especially in 1980 and 1981), and then with strong fluctuations in sprat fat content and stock biomass (Period IV) ${ }^{1}$. These years were also characterized by a rise in phytoplankton concentration (Mikaelyan 1997). The decrease in sprat fat content and biomass in 1983 was probably caused by an outburst in the abundance of the medusa Aurelia aurita, the major competitor of planktivorous pelagic fishes including sprat (Mironov 1971, Anninsky 1990, Niermann et al. 1994).

An analogous situation occurred at the end of the 1980s and the beginning of the 1990s when a mass explosion of the alien ctenophore Mnemiopsis leidyi undermined the food base of the planktivorous fishes (Vinogradov et al. 1992, Zaitsev 1993, Sorokin 2002). The data points for 1986 and 1987 differed considerably from the others (see Fig. 3B); this could be explained as follows: the food supply was decreased due to the extremely high sprat biomass in these 2 years.

Undoubtedly, the dynamics of fat content demonstrate the strong trophic competitive relationships of sprat in the Black Sea at the interspecies as well as the intraspecies levels. Long-term fluctuations of fat content show the limiting significance of food supply in the

\footnotetext{
${ }^{1}$ Dynamics of sprat biomass in the 1960s, 1970s and start of 1980s that were obtained from May stock surveys by YugNIRO (Domashenko et al. 1985) are somewhat different from data obtained for the entire sea estimated from several averaging methods (Prodanov et al. 1997)
}

biology of this species. If this were not the case, sprat fat content at the peak feeding period would only exhibit insignificant changes. Surely, this is not only valid for Black Sea sprat but also for all living organisms for which reserve lipids can provide the main sources of energy. In contrast to sprat, data on fat content of anchovy (another species occurring in high numbers in the Black Sea pelagial) are scarce for comparative studies. However, similar to sprat, the biomass of anchovy first increased during the 1970s and the early 1980s, and then sharply decreased at the end of the 1980s and the beginning of the 1990s (Domashenko et al. 1985, Prodanov et al. 1997, Chashchin 1998, Kideys 2002).

What are the reasons for the similarity in the longterm dynamics of the Black Sea sprat fat content with its stock dynamics (and with that of anchovy) as well as with phytoplankton biomass? First of all, there is undoubtedly a food supply effect on fish population via 2 channels: (1) accumulation of energy stores and (2) improving conditions for maturation, spawning and growth as a result of provision of reproductive and somatic processes with substance and energy. Energy stores are also undoubtedly significant for the survival of adult individuals during spawning and food deficiency (Shulman 1974, Shulman \& Love 1999). It is more difficult to explain similar long-term changes of sprat fat content with anchovy stock biomass. Surely both species show spatial and temporal variations (e.g. as opposed to cold-tolerant sprat, warm-tolerant anchovy increase in biomass in the second half of the year). One could assume that the main pelagial components would respond similarly to strong external influences in any ecosystem, including the Black Sea. In the present case, sprat is an 'indicator' species that 
characterizes the condition of the Black Sea pelagic ecosystem as a whole. The most difficult aspect to explain is the absence of complete correspondence in the general trend between the interannual dynamics of sprat fat content and biomass of total phytoplankton (Mikaelyan 1997) or chlorophyll a concentration (Yunev et al. 2002), as well as of the dynamics of nutrient concentrations (Konovalov et al. 1999). In the 1970 s, these parameters varied in the same direction. In 1980, a strong rise of sprat stock biomass and its high fat content corresponded well with a relatively high summer concentration of phytoplankton (Mikaelyan 1997), as well as with a high phytoplankton biomass during the winter-spring period (Bryantseva et al. 1996). In the following years, however, peak values in phytoplankton biomass did not correspond to sprat fat content. This was particularly clear in 1988 to 1990 when the mass explosion of the ctenophore Mnemiopsis leidyi occurred (Niermann et al. 1994, Shiganova et al. 2001, Kideys 2002). However, this case also has a wellgrounded explanation. The steady increase in eutrophication in the 1970s led to a high nutrient saturation in the 1980s (Prodanov \& Daskalov 1992, Vinogradov et al. 1992, Zaitsev 1993, Sorokin 2002). This eutrophication, which affected all levels in the trophic chain, caused the abundance and biomass of pelagic planktivorous fishes (anchovy and sprat) as well as those of competing animals at the same trophic level (i.e. Aurelia aurita and later $M$. leidyi) to increase. We can classify all these species in the upper trophic level for the Black Sea. Strictly speaking, there are higher trophic level animals such as predator fishes (e.g. horse-mackerel), sea birds and dolphins in this ecosystem, but their overall significance on the adjacent trophic level is not substantial (Sorokin 2002). According to some investigations, pelagic fishes (i.e. mainly anchovy and sprat) consume no more than $10 \%$ of the food zooplankton production in the Black Sea (Shulman \& Urdenko 1989, Shulman \& Love 1999, Sorokin 2002). In contrast, the medusa Aurelia and the ctenophore Mnemiopsis in the period of their peak explosion consumed up to $60 \%$ of the fodder zooplankton production (Anninsky 1990, Finenko et al. 2001, Sorokin 2002). Gelatinous organisms, being a cul-de-sac in the food chain, are in strong competition with planktivorous fishes, resulting not only in a decrease in fish stocks but also in the accumulation of fat reserves. It was for this reason alone that sprat fat content during the 1980s exhibited such sharp interannual fluctuations. We call these years the 'period of the rolling boat' (Period IV).

Over the next few years, a stabilization in Mnemiopsis abundance (Kideys \& Romanova 2001, Shiganova et al. 2001) led to the recovery of the food base of planktivorous fishes. Sprat stock biomass and fat content, therefore, increased (Periods V and VI) as did anchovy catches (Kideys et al. 1999). The data on chlorophyll a concentration were also in agreement with these events (Yunev et al. 2002), when the increased levels of mesozooplankton kept the primary production at moderate levels in response to the decreased nutrient input from major rivers.

It is worth noting the absence of similarity in interannual variations between sprat fat content (or sprat biomass) and food zooplankton biomass; this was contrary to expectations. The matter is complicated by the fact that these 2 trophic links are directly connected within a 'predator-prey' relationship and, therefore, mutually influence each other. Their interactions thus depend to a considerable extent on whether bottom-up or top-down processes prevail (Oguz et al. 2001). This is especially clear with respect to the Black Sea sprat. A steady decrease in the mesozooplankton biomass in the Black Sea pelagial stocks from the middle of the 1960 s to the end of the 1980s was accompanied by sharp increases in sprat stocks and fat content values, that is to say in food supply. This paradoxical phenomenon is demonstrated in Fig. 6, which reflects the dynamics of the ratio between the biomasses of food mesozooplankton and sprat. It is clearly shown that this ratio sharply decreased ( $>5$-fold) at the beginning of the 1970s in comparison to the preceding years and did not recover until the end of the 1980s. From Eqs. (2) to (4), it can be seen that this does not imply a worsening of sprat food supply, as during this period an increase in sprat biomass and fat content was observed, demonstrating an improvement in feeding conditions. Mesozooplankton biomass is controlled by predators (i.e. top-down), not so much by sprat, but to a higher degree by gelatinous organisms which graze

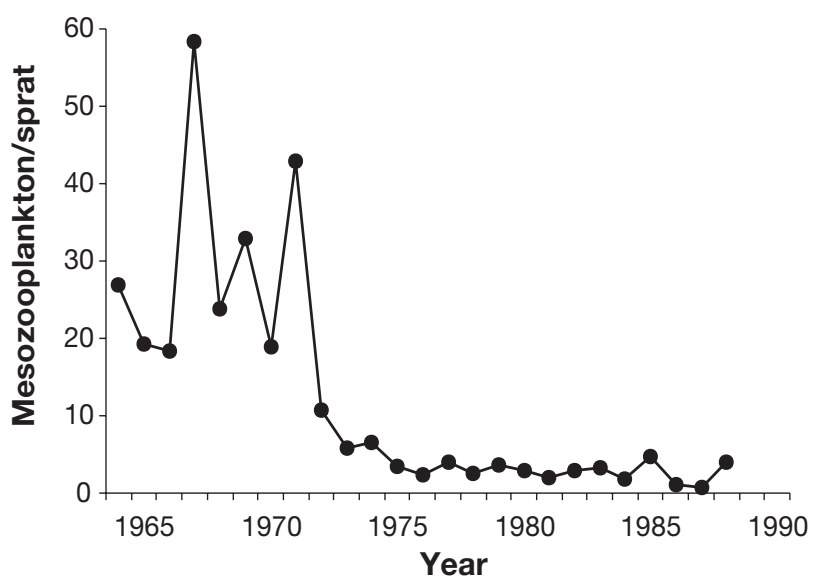

Fig. 6. Long-term changes in the ratio between the food mesozooplankton concentrations $\left(\mathrm{g} \mathrm{m}^{-2}\right)$ in the north-western part of the Black Sea and total sprat biomass $\left(\mathrm{g} \mathrm{m}^{-2}\right)$. The data presented in Figs. 3A \& 4 were recalculated using an average layer of $50 \mathrm{~m}$ depth for mesozooplankton and a total sea area of $423 \times$ $10^{3} \mathrm{~km}^{2}$ for sprat to obtain dimensionless values of the ratio 
considerably more on mesozooplankton than do small pelagic fishes. This fact provides additional confirmation of the considerable structural changes which occurred in the Black Sea at the beginning of the 1970s and brought about a transformation in the whole pelagic ecosystem (Vinogradov et al. 1992, Zaitsev 1993, Sorokin 2002). Based on analyses of the longterm dynamics of the main components of the Black Sea ecosystem as well as on results of modeling, considerable changes occurred in the pelagial trophic web in the early 1970s (Daskalov 2002). Specifically, if before the 1970 s zooplankton development was mainly limited by primary production levels, later this development was being controlled by small planktivorous fish and mainly by jellyfish. This, in our view, explains why there is an absence of correlation between the dynamics of zooplankton biomass and sprat fat content. It is widely known that the feeding base of planktivorous fishes is often estimated, not on the preceding trophic level, but instead on the phytoplankton biomass or primary production (Vucetic 1988, Caddy 1990, Caddy \& Griffiths 1990, Tudela 1992, Lalli \& Parsons 1997). In the Black Sea, successful comparisons between sprat stock biomass and phytoplankton concentration have been carried out by Samyshev (1997). Ideally, the condition of the feeding base of these fish should be estimated not from mesozooplankton biomass but rather from its production, which is very difficult to evaluate.

\section{Possible significance of climatic and anthropogenic factors}

Is it necessary to ask to what degree the observed variations in the Black Sea sprat condition and other characteristics of the pelagic ecosystem are the result of climatic (hydro-meteorological) or anthropogenic effects? We mention the last as eutrophication is caused by increased nutrient-rich river inflow and pollution. Fishery intensity may also be considered as an anthropogenic factor affecting the dynamics of fish stocks (Caddy \& Griffiths 1990, Gucu 2002). We think, however, that the sprat and anchovy removed by fisheries do not represent more than $30 \%$ of the total stocks in the Black Sea (Ivanov \& Beverton 1985). Such fishery levels are unlikely to be the primary influence on the long-term tendency of these characteristics for short-lived small pelagics; however, fishery undoubtedly affects stock structure.

Climatic factors, which have long-term regularity, probably contributed to the variations which occurred in the Black Sea pelagic ecosystem between the early 1960s and 1970s. This was a cooler period in the Black Sea (Ovchinnikov \& Osadchy 1991). Most of the 1970s and the entire 1980s were characterized by a warming period. During this period, both natural and anthropogenic factors contributed to high levels of all the characteristics considered (excluding mesozooplankton biomass). In the 1980s, intensive pollution added to eutrophication (Bologa et al. 1995, Konovalov 1995). During the peak of 'nutrient saturation', the 'immunity' of the pelagic ecosystem decreased sharply ${ }^{2}$. As a result, at the end of the 1980s, the immense explosion of the ctenophore Mnemiopsis leidyi occurred that led the Black Sea pelagic ecosystem and its main components to the brink of catastrophe. During the 1990s, naturalization of Mnemiopsis to this new environment took place. This was a period of reduced abundance due to decreased levels of mesozooplanktonn (Prodanov \& Daskalov 1992, Niermann et al. 1994, Kideys \& Romanova 2001, Shiganova et al. 2001). The appearance of the predator ctenophore Beroe ovata during the second half of the 1990s was a positive event for the ecosystem as it voraciously consumed Mnemiopsis, relaxing its pressure on mesozooplankton (Finenko et al. 2001, Kideys 2002), during the period when a reduction in eutrophication and pollution had also taken place (due to economic crises in most of the Black Sea countries). All of these factors were significant for the recovery of the pelagic ecosystem (Kideys 2002), including the condition of pelagic fish stocks and their food supply. A close and complex interaction of natural (climatic) and anthropogenic factors was, thus, responsible for the regulation of processes that occurred in the Black Sea ecosystem.

\section{Comparison with other marine basins}

How do the same parameters vary in other marine ecosystems? Does the situation in the Black Sea have a local character or does it reflect a more generalized (i.e. global) process occurring on our planet? We first consider the Mediterranean as it is the closest to the Black Sea. The Adriatic Sea, which is part of the Mediterranean, is the most similar to the Black Sea in respect to its hydrological and ecological features (Caddy 1990). Both the Adriatic and the Black Seas have, there are clearly expressed spatial water stratification, large river inflows and a vast shelf area in the northern part (analogous to of the north-western part of the Black Sea). The same pelagic fish species (different subspecies of anchovy Engraulis encrasicolus mediterraneus and sprat Sprattus sprattus sprattus) live in the Adriatic Sea. Unfortunately, we were not able to find references in the literature to any long${ }^{2}$ We mean 'immunity' as capacity for resistance to adverse
effects 
term data on the fat content of these species or in others (e.g. Sardina pilchardus) in the Adriatic Sea or in the Mediterranean as whole, which could be compared with extensive data on the Black Sea sprat. However, there are data on the long-term variability of stock biomass and catches for Adriatic sprat and anchovy (Vucetic 1988, Caddy 1990, Caddy \& Oliver 1994, Arneri 1996, Fiorentini et al. 1997, Cingolani et al. 1998, Sinovcic 2000, Azzali et al. 2001, Bombace 2001).

The data on sprat biomass variability in the Adriatic from 1977 to 1996 (Azzali et al. 2001) are similar to the data on Black Sea sprat fat content. Both increase similarly from the early 1970 s until the 1980s, biomass fluctuates strongly during the 1980s, falls catastrophically in 1989, and recovers in the first half of the 1990s. The sole discrepancy is that Adriatic stocks again sharply decreased during the second part of the last decade, the reason for which is not clear to us. The data on anchovy in the Adriatic Sea (Sinovcic 2000, Bombace 2001) show similar tendencies: the same steady biomass and catch increment from the 1970s to the 1980s and a sharp decrease in 1989 with an increase following in 1994. The abundance, biomass and primary production of phytoplankton in the Adriatic Sea behave in a similar manner (Vucetic 1988, Caddy 1990, Marasovich et al. 1998). The long-term dynamics of the hydrometeorological regime, eutrophication and pollution in the Adriatic Sea are, in general, similar to those in the Black Sea (Caddy 1990, Halim 1992, Konovalov 1995). These similarities indicate a common factor (or group of factors) acting on both ecosystems.

These factors include not only climate but also increased eutrophication and pollution. As for 'immunity', the Adriatic ecosystem also weakened towards the end of the 1980s, similarly to that of the Black Sea. Although the catastrophic events caused by Mnemiopsis invasion were absent in the Adriatic Sea, some other adverse phenomena caused by massive mucus accumulation (gelatinous aggregates, or so-called 'marine snow') took place (Maley 1995). This process decreased the oxygen concentration of the water and consequently caused considerable elimination of many components of the pelagic ecosystem. Unexpectedly, during this period, a considerable increase in biomass and catches of sardine was observed (Caddy 1990, Arneri 1996, Cingolani et al. 1998, Marano et al. 1998, Bombace 2001). Perhaps favorable environmental conditions for sardine do not conform to those for anchovy and sprat. The rise of phytoplankton biomass reveals an increase in nutrient levels in the Adriatic Sea. The sardine Sardina pilchardus may play the same role in the Adriatic Sea as the medusa Aurelia aurita and ctenophore Mnemiopsis leidyi in the Black Sea, namely an inhibitor for sprat and anchovy stocks. Nevertheless, fishery pressures on the increased phyto- plankton levels cannot be excluded (Caddy \& Griffiths 1990), although Bombace (2001) disagrees with this.

Data on other regions of the Mediterranean basin also show trends comparable with the Adriatic and Black Seas (Caddy \& Griffiths 1990, Caddy \& Oliver 1994, Lleonart \& Recasens 1996, Fiorentini et al. 1997). This includes the anchovy stock biomass and catches in the Ionian and the Aegean seas (Stergiou 1988), the Tyrrhenian Sea (Arneri 1996, Bombace 2001), Lyons Bay, Catalonia region, the Bolear and the Andaluse Seas (Lopez-Cazorla \& Sanchez 1986, Pertierra \& Lleonart 1992). In the Catalonia region, a relationship between anchovy catches and primary production was reported (Tudela 1992).

Moreover, some other data show that similar interannual dynamics are also observed in other seas of the Atlantic basin (Caddy 1990, Laevastu 1993). Similar fluctuations were found in many species among which we only mention a few: Iceland herring Clupea harengus harengus (Bakken 1983), Iceland and Barents capelin Mallotus vilosus vilosus (Yakobsson 1991), Benguela anchovy Engraulis meridionalis (LluchBelda et al. 1992), South African anchovy E. capensis (Shelton et al. 1993), California anchovy E. mordax and California sardine Sardinops caerulea and Japanese sardine S. sagax melanostica (Lluch-Belda et al. 1992). In all of these cases, a rise of stock biomass and catches from the 1970 s to 1980 s, a strong fall at the end of the 1980s, and a recovery (in those cases where data are available) in the 1990s were observed.

Undoubtedly, the long-term fluctuations revealed have a global character as was suggested by Niermann et al. (1999), who analyzed the dynamics of plankton biomass in the World Ocean, and by Klyashtorin (1998, 2003) who studied the dynamics of catches and stock biomass of marine fishes. The latter scientist related these dynamics with the long-term oscillations in the rotational velocity of the Earth as affecting the intensity of circulation in the oceans. A significant amount of information considering the regularity of climatic changes in the World Ocean that are relevant to the dynamics of fish stocks can be found in the publications of Levitus (1994), Doumenge (1997), Issar (1997), and Lalli \& Parsons (1997).

We conclude that: (1) data on fish fat content (as we have demonstrated using the the Black Sea sprat as an example) provide a powerful indicator for characterizing one of the most important features of stock condition (i.e. food supply); (2) this indicator is closely related to other characteristics of stock condition (especially with biomass); (3) due to the simple and rapid method of determination, which allows large numbers of field samples, fish fat content could be used as an indispensable parameter for monitoring the general condition of populations as well as of pelagic ecosystems. 
Acknowledgements. This work was supported by State Programs of the National Academy of Sciences of Ukraine (No. 3.3.4.3/09.01.1996 and No. 3.3.4.3/19.01.1999) and a Linkage Grant (ENVIR.LG: 97.3262) from NATO. We thank the crews of Research Vessels of IBSS and YugNIRO as well as of commercial vessels which helped us in sample collection.

\section{LITERATURE CITED}

Ackman RG (1980) Fish lipids. Part 1. In: Conell JJ (ed) Advances of fish science and technology. Fishery News Books, Oxford, p 86-103

Anninsky BE (1990) Energy balance of medusae Aurelia aurita in the Black sea condition. In: Shulman GE, Finenko GA (eds) Bioenergetics of hydrobionts. Naukova Dumka, Kiev, p 11-32 (in Russian)

Arnery E (1996) Fisheries resources assessment and management in the Adriatic and Ionian seas. FAO-CFCM Third Technical Consultation on Stock Assessment in the Central Mediterranean. Tunis 8-12 November 1994. FAO Fish Rep 533(Suppl):7-20

Azzali M, Cosini G, Luna (2001) Fluctuations in space and time of pelagic populations in the Adriatic sea from 1976 to 1996. Arch Oceanogr Limnol 22:127-132

Bakken E (1983) Recent history of Atlanto-Scandinavian herring stocks. FAO Fish Rep 291:521-536

Bologa AS, Bodeanu N, Petran A, Tiganus V, Zaitsev YuP (1995) Major modification of the Black Sea benthic and planktonic biota in the last three decades. Bull Inst Oceanogr 15:85-110

Bombace G (2001) Influence of climatic changes on stocks, fish species and marine ecosystems in the Mediterranean sea. Arch Oceanogr Limnol 22:67-72

Bryantseva YuV, Bryantsev VA, Kovalchuk LA, Samyshev EZ (1996) For the question of long-term changes of biomass in diatom and peridinien algaes of the Black sea in relation with atmospheric activity. Ekologiya Morya 45:13-18 (in Russian)

Caddy JF (1990) Tendences récents des pêches méditerrannées. Etude et Revues (Conseil Général des Pêches pour la Méditerranée), FAO, Rome, p 1-54

Caddy JF, Griffiths RC (1990) A perspective on recent fisheryrelated events in the Black sea. In: Recent trends in the fisheries and environment in the general fisheries for the Mediterranean (GFCM) area. GFCM Stud Rev 63: $43-71$

Caddy JF, Oliver P (1994) Some future perspectives for assessment and management of Mediterranean fisheries for demersal and shellfish resources, and small pelagic fish. In: Caddy JF (ed) Resource and environmental issues relevant to Mediterranean fisheries management. GFCM Stud Rev 66:19-60

Chashchin AK (1998) The anchovy and other pelagic fish stocks transformations in the Azov-Black Sea Basin under environmental and fisheries impact. In: Celikkale MS, Duzgunes E, Okumus J, Mutlu C (eds) The Proceedings of the First International Symposium on Fisheries and Ecology. 2-4 Sept. 1988, Trabzon, Turkey, p 1-10

Cingolani N, Arneri E, Gianetti G, Santojanni A, Belardinelli A (1998) Assessment of anchovy and sardine stocks in the Adriatic sea by means of population dynamics. Biol Mar Medit 5(3):321-330

Daskalov GM (2002) Overfishing drives a trophic cascade in the Black Sea. Mar Ecol Prog Ser 225:53-63

Domashenko GP, Mikhailyuk AN, Chashchin AK, Shlyakhov
VA, Yuriev GS (1985) Modern state of commercial stocks of anchovy, sprat and whiting in the Black Sea. In: Shlyakhov VA (ed) Oceanological and fishery investigations of the Black Sea. Agropromizdat, Moscow, p 87-100 (in Russian)

Doumenge F (1997) The Mediterranean crises: is it a positive or negative process? UN university lecture, The United Nations University, UNU Headquarters on 15 July 1996 and at the Global Environment information Centre (GEIC) in November 1996, Tokyo, p 2-10

Finenko GA, Anninsky BE, Romanova ZA, Abolmasova GI, Kideys AE (2001) Chemical composition, respiration and feeding rates of the new alien ctenophore, Beroe ovata, in the Black Sea. Hydrobiologia 451:177-186

Fiorentini L, Caddy JF, de Leiva JI (1997) Long- and shortterm trends of Mediterranean fishery resourses. GFCM Stud Rev 69:1-14

Fraser AJ, Gamble JC, Sargent JR (1988) Changes in lipid content, lipid class composition of developing eggs and unfed larvae of cod (Gadus morhua). Mar Biol 89:307-313

Gucu AC (2002) Can overfishing be responsible for the successful establishment of Mnemiopsis leidyi in the Black sea? Estuar Coast Shelf Sci 54:439-451

Hakanson JL (1989a) Analysis of lipid components for determining the condition of anchovy larvae Engraulis mordax. Mar Biol 102:143-151

Hakanson JL (1989b) Condition of larval anchovy (Engraulis mordax) in the Southern California Bight, as measured through lipid analysis. Mar Biol 102:153-160

Halim J (1992) Pollution problems in the Mediterranean Sea. Bull Inst Oceanogr 11:27-42

Hardy R, Mackie PR (1969) Seasonal variations in some of the lipid component of sprat (Sprattus sprattus). J Sci Food Agric 20:193-198

Issar A (1997) Climate change: Is it a positive or negative processes? UN university lecture, The United Nations University, UNU Headquarters on 15 July 1996 and at the Global Environment information Centre (GEIC) in November 1996, Tokyo, p 10-13

Ivanov LS, Beverton RJH (1985) The fisheries resources of the Mediterranean. Part 2: Black Sea. GFCM Stud Rev 60: $1-135$

Kideys AE (2002) Fall and rise of the Black Sea ecosystem. Science 297:1482-1484

Kideys AE, Romanova ZA (2001) Distribution of macrogelatinous zooplankton in the southern Black Sea during 1996-1999. Mar Biol 139:535-547

Kideys AE, Gordina AD, Bingel F, Niermann U (1999) The effect of environmental conditions on the distribution of eggs and larvae of anchovy in the Black sea. ICES J Mar Sci 56(Suppl):58-64

Klyashtorin LB (1998) Long-term climate change and main commercial fish production in the Atlantic and Pacific. Fish Res 37:115-125

Klyashtorin LB (2003) Climate change and long-term fluctuations of commercial catches. The possibility of forecasting. FAO Fish Tech Pap 410:1-86

Konovalov SK, Ivanov LI, Murray JW, Eremeeva LV (1999) Eutrophication: a plausible cause for changes in hydrochemical structure. In: Besiktepe ST, Umluata U, Bologa AS (eds) Environmental degradation of the Black Sea: challenges and remedies. NATO Science Series. 2. Environmental Security Vol 56. Kluwer Academic Publishers, Dordrecht, p 61-74

Konovalov SM (1995) Anthropogenic impact and ecosystems of the Black Sea. Bull Inst Oceanogr 15:53-82

Kovalev AV, Gubanova AD, Kideys AE, Melnikov VV and 6 
others (1998) Long-term changes in the biomass and composition of fodder zooplankton in coastal regions of the Black Sea during the period 1957-1996. In: Ivanov I, Oguz $\mathrm{T}$ (eds) Ecosystem modeling as a management tool for the Black Sea. NATO Science Series. 2. Environmental Security, Vol 47(1). Kluwer Academic Publishers, Dordrecht, p 209-219

Kreps EM (1981) Lipids of cell membranes. Nauka, Leningrad (in Russian)

Laevastu T (1993) Marine climate, weather and fisheries. Halstead Press, New York

Lalli CM, Parsons TR (1997) Biological oceanography. An introduction. 2nd edn. Butterworth \& Heinemann, Oxford

Levitus S (1994) World ocean atlas. Inform Rep No. 13, National Oceanographic Data Center, Ocean Climate Laboratory, Washington, DC

Lleonart J, Recasens L (1996) Fisheries and environment in the Mediterranean Sea. In: Caddy JF (ed) Resource and environmental issues relevant to Mediterranean fisheries management. GFCM Stud Rev 66:5-18

Lluch-Belda D, Schwartzlose RA, Serra R, Parrish RH, Kawasata T, Hedgecock D, Crawford RJM (1992) Sardine and anchovy regime fluctuations of abundance in four regions of the world oceans: a workshop report. Fish Oceanogr 1(4):339-347

Lopez-Cazorla A, Sanchez PE (1986) Evaluacion del stock de la anchoa, Engraulis (L), de la pesqeria de Cataluna, a partir de datos de frecuencias de tallas. Bol Inst Esp Oceanogr 3:67-72

Love RM (1970) The chemical biology of fishes, Vol 1. Academic Press, London/New York

Love RM (1980) The chemical biology of fishes, Vol 2. Academic Press, London/New York

Lovern JA (1964) The lipids of marine organisms. Oceanogr Mar Biol Annu Rev 2:169-191

Maley A (1995) Gelatinous aggregates in the northern Adriatic Sea. Bull Inst Oceanogr 15:149-157

Marano G, Casavola N, Rizzi E, De Ruggieri P, Lo Capulo S (1998) Valutazione delle risorse stock di sardine e alici nell'Adriatico meridionale. Anni 1984-1996. Biol Mar Medit 5:313-320

Marasovich I, Pucher-Petkovic T, Hernandez A (1998) Phytoplankton productivity of the Adriatic Sea in relation to pelagic fisheries. Biljeske-Notes 72:1-8

Mikaelyan AS (1997) Long-term variability of phytoplankton communities in the open Black Sea in relation to environmental changes. In: Ozsoy E, Mikaelyan A (eds) Sensitivity to change: Black Sea, Baltic Sea and North Sea. Kluwer Academic Publishers, Dordrecht, p 105-116

Minyuk GS, Shulman GE, Shchepkin VYa, Yuneva TV (1997) Black Sea sprat: the relationship between lipid dynamics, biology and fishery. Ekosi-Hydrophysica, Sevastopol (in Russian)

Mironov GN (1971) Biomass and distribution of medusa Aurelia aurita according to the catches with the bottom trawl in the Black Sea in the period 1942-1962. Biologiya Morya 14:49-69 (in Russian)

Niermann U, Bingel F, Gerban A, Gordina AD and 6 others (1994) Distribution of anchovy eggs and larvae in the Black Sea in 1991-1992. ICES J Mar Sci 51:395-406

Niermann U, Kideys AE, Kovalev AV, Melnikov V, Belokopytov V (1999) Fluctuations of pelagic species of the ocean and Black Sea during 1980-1995. In: Besiktepe ST, Umluata U, Bologa AS (eds) Environmental degradation of the Black Sea: challenges and remedies. NATO Science Series. 2. Environmental Security, Vol 56. Kluwer Academic Publishers, Dordrecht, p 147-174
Oguz T, Ducklow HW, Purcell JE, Malanotte-Rizzoli P (2001) Modeling the response of top-down control exerted by gelatinous carnivores on the Black Sea pelagic food web. J Geophys Res 106:4543-4564

Ovchinnikov IM, Osadchy AS (1991) Secular variability of winter climatic conditions influencing peculiarities of hydrological conditions in the Black Sea. In: Variability of the Black Sea ecosystem. Nauka, Moscow, p 85-89 (in Russian).

Pertierra JP, Lleonart J (1992) A study of the population dynamics of the Northwestern Mediterranean anchovy using LCA (length cohort analysis). Rapp PV Reun 33:252

Prodanov K, Daskalov G (1992) Stock assessments of sprat along Bulgarian Black Sea coast (1976-1990). Rapp PV Reun 33:305

Prodanov K, Mikhailov K, Daskalov G, Maxim K, Chashchin A, Arkhipov A, Shlyakhov V, Ozdamar E (1997) Environmental management in the Black Sea and their rational exploitation. GFCM Stud Rev No 68. FAO, Rome

Samyshev EZ (1997) Forecasting of sprat stock in the Black Sea. Rybnoe Khozyaistvo 6:40-42 (in Russian)

Shatunovsky MI (1980) Ecological regularities in marine fishes. Nauka, Moscow (in Russian)

Shelton PA, Armstrong MJ, Rool BA (1993) An overview of the application of the daily egg production method in the assessment and management of anchovy in the Southern Atlantic. Bull Mar Sci 53:778-794

Shiganova TA, Mirzoyan ZA, Studenikina EA, Volovik SP and 5 others (2001) Population development of the invader ctenophora Mnemiopsis leidyi in the Black Sea and in other seas of the Mediterranean basin. Mar Biol 139:431-445

Shulman GE (1960) Dynamics of fat content of the fish body. Uspekhi Sovremennoy Biologii 49:225-239 (in Russian)

Shulman GE (1963) Determination of fish food supply. Zool Zh 42:581-588 (in Russian)

Shulman GE (1966) Dynamics of fat content in the body of some Black Sea fishes. Proceedings of Azov-Black Sea Institute of Marine Fish Oceanogr 24:183-197 (in Russian)

Shulman GE (1974) Life cycles of fish. Physiology and biochemistry. Hulsted Press, John Wiley \& Sons, New York

Shulman GE, Dobrovolov IS (1979) The state of affairs in ecologo-physiological studies of Black Sea fishes. In: Greze VN (ed) The foundations of biological productivity of the Black Sea. Naukova Dumka, Kiev, p 321-340 (in Russian)

Shulman GE, Love RM (1999) The biochemical ecology of marine fishes. Adv Mar Biol 36:1-352

Shulman GE, Urdenko SYu (1989) Productivity of fishes of the Black Sea. Naukova Dumka, Kiev (in Russian)

Shulman GE, Chashchin AK, Minyuk GS, Shchepkin VYa, Nikolsky VN, Dobrovolov IS, Dobrovolova SG, Zhigunenko AS (1994) Long-term monitoring of Black Sea sprat condition. Doklady Akademii Nauk 335:124-126 (in Russian)

Sidorov VS (1983) Ecological biochemistry of fish lipids. Nauka, Leningrad (in Russian)

Sinovcic G (2000) Anchovy, E. encrasicolus: biology, population dynamics and fisheries case study. Acta Adriat 41:3-53

Sorokin YuI (2002) The Black Sea. Ecology and oceanography. Backhuys Publisher, Leiden

Stergiou KI (1988) Multivariate analysis of the commercial fishery of the Northwestern Coast of Greece, 1984-1981. Acta Adriat 29:161-170

Svetovidov AN (1964) The fishes of the Black Sea. Nauka, Moscow, Leningrad (in Russian)

Tudela S (1992) Assessment of the ecological footprint of fishing in the Catalon central coast (NE Spain). CIESM Workshop series. Bull Comm Int Explor Sci Mer Mediter 12:79-82 
Vedernikov VI, Demidov AB (1993) Primary production and chlorophyll in the deep regions of the Black Sea. Okeanologiya 33(2):229-235 (in Russian)

Vinogradov ME, Sapozhnikov VV, Shushkina EA (1992) The Black Sea ecosystem. Nauka, Moscow (in Russian) Vucetic T (1988) Long-term (1960-1983) fluctuations of zooplankton biomass in the Palagruze-Gargano area. FAO Fish Rep No 394. FAO, Rome

Yakobsson Y (1991) Recent variability in fisheries of the North

Editorial responsibility: Otto Kinne (Editor-in-Chief), Oldendorf/Luhe, Germany
Atlantic. ICES N 21 Variability Symp, p 1-12

Yunev OA, Vedernikov VI, Basturk O, Yilmaz A, Kideys AE, Moncheva S, Konovalov SK (2002) Long-term variations of surface chlorophyll $a$ and primary production in the open Black Sea. Mar Ecol Prog Ser 230:11-28

Zaitsev YuP (1993) Impacts of eutrophication on the Black Sea fauna. GFCM Stud Rev 64:63-85

Zar JH (1984) Biostatistical analysis, 2nd edn. Prentice Hall, Englewood Cliffs, NJ

Submitted: March 23, 2004; Accepted: September 21, 2004 Proofs received from author: May 6, 2005 